\title{
Mary Parker Follett as Integrative Public Philosopher
}

\author{
Matthew J. Brown (D) \\ Center for Values in Medicine, Science, and Technology, The University of Texas at Dallas, \\ 800 W. Campbell Rd. JO 31, Dallas, TX 75080 \\ Corresponding author. Email. mattbrown@utdallas.edu
}

(Received 29 September 2019; revised 4 January 2021; accepted 8 January 2021)

\begin{abstract}
Mary Parker Follett was a feminist-pragmatist American philosopher, a social-settlement worker, a founding figure in the community centers movement, a mediator of labor disputes, and a theorist of political and social organization and management. I argue that she is a model for a certain kind of public philosopher, and I unpack the respects in which she serves as such a model. I emphasize both her virtues as a public thinker and the role played in her work by the process of integration and the creative process.
\end{abstract}

Common complaints about contemporary social and political issues in America and Europe emphasize partisanship, divisiveness, and the degradations and failures of democracy (Drutman 2017; Carpenter 2019). Corrupt politicians like Donald J. Trump use nationalism and racism to divide the population while they hamper or destroy key social institutions and plunder the public coffers (Packer 2020; Sherman 2020). All eyes are on electoral politics, particularly in the US, for a solution to this problem, but this seems to mask the underlying issues. How can we make social progress and address the major public problems of our time with such a divided polis? And what role can philosophy play in all this? I believe we should turn to the life and work of Mary Parker Follett (1868-1933) for lessons relevant to these difficult times.

Follett was an original and significant American philosopher who, until recently, has been absent from the canon and underappreciated by academic philosophers, much as Jane Addams had been until the end of the twentieth century. Today, Follett is still remembered and written about more in management, business, and public administration circles than in philosophy. Recently, thanks to John Kaag, Scott Pratt, Judy Whipps, and Margaret Stout and Jeannine Love, among others, Follett is coming to be seen as a distinctive feminist-pragmatist philosopher in her own right (Kaag 2008; Pratt 2011; Stout and Love 2014; Whipps 2014; Stout and Love 2015). Erin McKenna and Scott Pratt have woven her story into their wonderful narrative about the American philosophical tradition of resistance and pluralism (McKenna and Pratt 2015).

(C) The Author(s), 2021. Published by Cambridge University Press on behalf of Hypatia, a Nonprofit Corporation. This is an Open Access article, distributed under the terms of the Creative Commons Attribution licence (http://creative commons.org/licenses/by/4.0/), which permits unrestricted re-use, distribution, and reproduction in any medium, provided the original work is properly cited. 
In addition to her relevant and original philosophical thought, Follett is also a model for a certain kind of public philosopher. According to Sharon Meagher, co-founder of the Public Philosophy Network, "Public philosophy should not be confused with mere publicity or celebrity"; instead, "Public philosophy should be transformative" (Meagher 2013, 5-8). According to James Tully, "The role of a public philosophy is to address public affairs . . . by trying to enter into the dialogues with citizens engaged in struggles against various forms of injustice and oppression" (Tully 2008, 3). One of the key themes in discussions of public philosophy is that philosophers have particular skills that enable them to address major social problems and controversies and facilitate integration of conflicting perspectives. I will argue that we should take Follett as a model of a public philosopher through five important elements of her work:

1. Her philosophical work is consistently engaged, with problems of social work, activism, labor relations, politics, business, and so on.

2. Her writing is interdisciplinary and voracious; she draws on (and often contributes to) ideas in psychology, social science, political economy, biology, mathematics, physics, and various traditions in philosophy.

3. Her work is adaptable and opportunistic in a positive sense; Follett's work responds to the needs of her time and place and the opportunities presented to her, and she adapts it to new and changing situations.

4. Her work is rigorous in a specific way; it is empirically and theoretically grounded, clearly argued, with a solid basis in practice.

5. Her writing is accessible, speaking to a broad audience, not just to other academics.

What particularly distinguishes Follett's work from some other examples of public philosophy are 2, 3, and 4 . Her work is never narrowly disciplinary, as many examples of "applied philosophy" are. We see Follett's opportunism in her turn from political science to labor and business issues, and her ability to adapt her focus and her emphasis to have an impact on those debates. And she never forsakes rigor or gives in to broad, vague formulations of her ideas. In terms of rigor, as mentioned previously, Follett's notion of rigor was staunchly opposed to that of the armchair philosopher. On this point, she differs substantially from her critic, the proto-analytic philosopher Morris R. Cohen, who held that philosophical clarity and rigor comes from distancing oneself from real-world problems; Cohen criticized Follett in particular for failing to do so (see discussion in McKenna and Pratt 2015, 122-33).

In order to understand Follett as a public philosopher, we have to look at the intertwining story of her intellectual work and the elements of her life and career that exemplify her approach to public philosophy. In terms of her philosophical ideas, I will focus especially on her views on the process of integration and the creative process. In the following sections, I will explore the ways in which she exemplifies features 1-4 above. By frequent, occasionally extended quotation of Follett's own text, I will exhibit 5 as well.

\section{SOCIAL ENGAGEMENT}

The first dimension of public philosophy one finds in Follett's work is social engagement-that is, direct interaction with individuals and groups in order to address the needs of social work, labor relations, and politics. Rather than merely propounding 
theories or engaging in commentary from a removed position, she engaged directly with people, organizations, and communities on particular issues. Follett was a socially engaged philosopher of democracy, of community life, and of social organization. She was a pragmatist-idealist ${ }^{1}$ in a vein similar to Josiah Royce; she built on Royce's philosophy of community while giving it her own particular spin, without explicitly relying on the metaphysics of the Absolute. ${ }^{2}$ Follett thought American democracy was more an ideal and a promissory note than an existing reality, and she laid out an inspiring vision of participatory democracy founded in experience, understood as creative and future-oriented. Follett's unique ideas and emphases should be of keen interest in themselves to pragmatist philosophers and political theorists, in particular, her analyses of diversity and of power (see Pratt 2011; Whipps 2014).

Follett started out working in a social settlement in the Roxbury neighborhood of Boston, serving poor or working-class, largely immigrant communities. Her first major project involved getting men involved with the settlement in the predominantly Irish immigrant neighborhood; women and children made more use of the services of the settlement house, whereas young men tended to stay away. Follett created a young men's debate club, the Highland Union, focused on political issues, which piqued the men's interest and helped them develop key skills for citizenship. She developed this club into a broader educational program in civics, history, economics, and social education. Many of the young men who had been a part of the club went on to major political or professional careers (Tonn 2003, 127).

Follett was a founder of the community centers movement, and she helped bring about creation of several community centers throughout Boston. Joan Tonn describes Follett's motivations in moving from the social settlement to creating community centers as based in her dissatisfaction with the social settlement's ability to "foster community." Follett's new efforts focused on civic responsibility and engagement. She worked to create democratically administered organizations that would prepare members to participate in democratic governance at a wider level (5).

Follett worked with the Boston Equal Suffrage Association for Good Government and the Women's Municipal League of Boston. Follett, like several feminists of her time, opposed the single-minded focus on women's suffrage pushed by some, because she saw that voting was not the sine qua non of democracy, but only a means to it. She opposed technocratic and ward-boss-run machine politics for the same reasons: she wanted the people to learn to govern themselves. In 1908, she was the chairperson of the Women's Municipal League's Committee on Extended Use of School Buildings, and in 1911 she founded the East Boston High School Social Center. In 1917, Follett was elected vice president of the National Community Center Association.

Follett consulted on a variety of labor and management issues, from forming jobplacement bureaus connected to the local schools in Boston (Tonn 2003, 219) to advising the International Labor Organization in Geneva (Stout and Love 2016, 1503). In 1920, she was appointed to the Massachusetts Minimum Wage Board, where she worked as a representative of the public to mediate disputes between employers and employees and became increasingly involved with labor negotiations (Follett 1924, 14-15; Whipps 2014, 408).

This level of social engagement is seen not only in Follett's practice of engaging with local communities and neighborhood groups through the settlement and community centers, through her work on labor issues and workplace organization, or through her dissatisfaction with the state of contemporary politics. These situations of social 
engagement also inform Follett's discussion of the process of integration, which exhibits the relation of theory and practice in her work.

Follett is particularly interested in social processes of group decision-making, in which individuals with differing experiences, aims, and values come together to make a decision. Such situations can go in a few different ways. One set of interests can dominate another, a problematic exercise in what she calls "power-over." Or the competing interests can reach a compromise in which everyone gets a little of what they want. This, too, is problematic, unsatisfying, unstable, and a matter of "balancing" coercive power. In The New State she asserts, "In a way all compromise is insincere" (Follett 1918, 114). The parties to a compromise are not satisfied and not inclined to be at peace with the compromise position. Detente between attempts at coercion does not amount to cooperation.

The critique of compromise is a rather unusual element of Follett's social philosophy, and she unpacks the problems with compromise again in Creative Experience:

In compromise, I say, there is no qualitative change in our thinking. Partisanship starves our nature: I am so intent on my own values that other values have got starved out of me; this represents a loss in my nature, in the whole quality of my personality. Through an interpenetrating of understanding, the quality of one's own thinking is changed; we are sensitized to an appreciation of other values. By not interpenetrating, by simply lining up values and conceding some for the sake of getting the agreement necessary for action, our thinking stays just where it was. In integration all the overtones of value are utilized. (Follett 1924, 163)

Not only are the parties to a compromise inevitably dissatisfied with the results; on Follett's view, compromise tends to narrow our thinking, reduce our appreciation for the variety of values, and decrease our empathy. With compromise as the main mechanism of resolving conflicts, there is no genuine possibility of social progress, only a back and forth struggle to get the better of the shifting compromise. Though in an obvious sense, compromise is better than domination, both are exercises in coercive power. By contrast, cooperation and integration require the expansion of everyone's thinking and appreciation, involving empathetic recognition of the values cherished by our interlocutors.

Follett wants us to reject coercive power in favor of what she calls "coactive power" or "power-with," a sense of power that is genuinely nondominating. This sort of power is "genuine," whereas coercive power is a "curse":

Genuine power can only be grown, it will slip from every arbitrary hand that grasps it; for genuine power is not coercive control, but coactive control. Coercive power is the curse of the universe; coactive power, the enrichment and advancement of every human soul. (Follett 1924, xiii)

Genuine, coactive power is connected with the process of integration as both a precondition of the process and something that grows as a result of successful integration. In integration, the diversity of individuals is preserved, but a common will is formed. The variety of values that individuals bring to a negotiation are enriched and strengthened rather than sacrificed.

In The New State Follett describes the process of integration in concrete terms: 
We sit around the council table not blank pages but made up of all our past experiences. Then we evolve a so-called common will, then we take it into the concrete world to see if it will work. In so far as it does work, it proves itself; in so far as it does not, it generates the necessary idea to make it "common." (Follett 1918, 50)

Crucially, the process of integration is not the capitulation of the individual will to the will of the group. This would be another coercive form of power. A common will is common just insofar as it successfully integrates the individual experiences and values of those who contribute to it. Rather than replacing individual values with the common good, the individuals who create a common will place their own will in a broader context that incorporates it. In turn, the individuals commit to the shared project that the common will represents. Or, as Follett puts it in a memorable turn of phrase, "the will to will the common will is the core, the germinating centre of that large, still larger, ever larger life which we are coming to call the true democracy" (Follett 1918, 49). This concept of integration very much comes out of her experience with small-scale democratic practice. Whether engaged in a committee meeting or a labor negotiation, the proposed process of integration serves a perceived need in that situation.

\section{VORACIOUS INTERDISCIPLINARITY}

Follett's public philosophy is also characterized by its voracious interdisciplinarity. She moves between discourses in various fields in the natural and social sciences as well as philosophy. She is particularly skilled in making insights from one field comprehensible to and meaningful for another and synthesizing multiple fields to create disciplinedefining insights. Though Follett was a philosophical thinker, she never had a purely academic career, nor was she ever clearly demarcated as a professional philosopher. She wrote a political history, The Speaker of the House of Representatives (Follett 1896), begun during her studies with the economic historian William James Ashley (Tonn 2003, 107-8). She wrote a work of political science recommending a very different form of governmental organization, The New State: Group Organization the Solution of Popular Government (Follett 1918). Her book Creative Experience (Follett 1924) is a discipline-defying exploration of philosophy, psychology, and social theory. Follett published and presented essays and articles in fields including philosophy, history, political science, business organization and management, and well as to a variety of public and professional groups and organizations.

Returning to the concept of integration, we can see further interdisciplinary connections drawn in Follett's work. We have already seen in the previous section the role of integration in social philosophy and political theory. As compared to Follett's own presentation, this is somewhat backwards. According to Follett, integration also takes place at an individual, psychological level, and this forms somewhat the model for the social and political processes of integration. Follett sees the individual as a node in a network of relations, as a collection of drives, values, and ideas that must be integrated into a personality and an individual will. She explicitly adopts a Freudian notion of psychological health as integration of the various drives (or "wishes") into a whole, functioning personality (Follett 1919, 576-77). This contrasts with the unhealthy repression of one drive by another. The social process of integration is analogous, or perhaps literally the same process at the level of the group.

The influence of psychological concepts is also clear in Creative Experience. In the introduction, Follett begins with the problem of method in the social sciences as well 
as the need for more strongly grounded concepts (Follett 1924, ix) -about which more below. She quickly turns to biology, physiology, and especially psychology as a source of guidance for the social scientist. In subsequent chapters, she draws on a variety of fields. Her work frequently engages with issues of jurisprudence, philosophy of law, and legal history, including drawing on and responding to the work of Josef Kohler, Benjamin Cardozo, and Oliver Wendell Holmes, Jr. She engages with psychologists from Freud to Wolfgang Koehler to William James to Edwin Holt. And throughout she weaves together considerations of metaphysics, psychology, politics, and social philosophy, into both a rich conception of the agenda for the social sciences and for political engagement and reform.

\section{OPPORTUNISM AND ADAPTABILITY}

Another key element of Follett's public philosophy is what we might call her opportunism or adaptability. Although those terms could have negative connotations, I mean them in an entirely positive sense: Follett's work responds to time and place, the specific requirements and needs of particular dynamic situations. Those who label Follett a "pragmatist" (for example, Snider 1998) tend to emphasize her situational or contextual approach, and reference to concrete situations is pervasive in Follett's work.

At the urging of business leaders who had helped her with her civic endeavors, Follett started to work in business management, focused on egalitarian and workplace democracy approaches to organization. As mentioned previously, she was appointed to the Massachusetts Minimum Wage Board in 1920 (Whipps 2014, 408). This work inspired her to search for a new process for resolving conflicts in groups, and that search inspired the ideas behind her 1924 publication of Creative Experience (Tonn 2003 , 4). In turn, after the book's publication, Follett consulted with business leaders to resolve labor disputes using the methodology of "community integration" described in that book, among other management and organizational problems. ${ }^{3}$ As Keith Snider has pointed out, this change of audience from one that included philosophers occasioned a change in voice or idiom and a tendency to de-emphasize the radical elements of her thought, such as her anti-individualism and emphasis on noncoercive social unity, especially the emphasis on submission of the individual to the common will (Snider 1998, 277-78). Works post-1924 tended to talk about "co-ordination" rather than "unity" and avoided the metaphysical or "mystical" elements (Snider 1998, 280-81).

Snider sees her shift of voice or language as well as the shift in emphasis not as a form of cynicism or compromise, but as being true to her pragmatism and her account of what she calls "the law of the situation" (280-81; cf. Follett 1924, 152; Stout and Love 2014, 18-19). In a business administration context, Follett recommends a management style that avoids and depersonalizes "giving orders," and emphasizes instead working cooperatively to address the needs of the shared situation: "to unite all concerned in a study of the situation, to discover the law of the situation and obey that" (Follett 1942, 29). For Follett this is not just a management technique to get workers to do what you want; it leads to more effective collective action through responding to the requirements of a total situation. When the social situation Follett found herself in required that she either shift idiom or lose her audience, she wisely pivoted. This is the sort of adaptability to new opportunities and situations that public philosophy requires.

Follett's emphasis on opportunism and adaptability is reflected in the significance of creativity in her work. Integration is creative, a process of invention. It creates 
something new, it leads to the growth of individuals and communities, and it creates "power-with" rather than the zero-sum balancing of power-over. It is precisely the creativity of the integrative process that enables it to go beyond compromise and to inclusively integrate values that might seem, at first, to constitute a conflict.

Here are three examples of the process of integration from Creative Experience:

1. If you are trying to decide whether you will go to New York by boat or by train, and are weighing the advantages-fresh air, etc., on the one hand, speed, etc., on the other-and a friend comes along and offers to take you in his aeroplane, where you will have the advantages of both train and boat, that is an integration. (Follett 1924, 157)

2. At a meeting of our manufacturing committee recently the following question came up. Our paper had been six cents, and the competing firm reduced their price to five and three-quarters. We then cut to five and a half and they replied with a price of five and a quarter. The question before us then was whether or not we should make a further reduction. Part were in favor; part, against. The solution came when something quite different was suggested: that we should stand for a higher quality of paper and make an appropriate price for it. (158)

3. For instance, some friends of mine could not agree on a school for their boy: the man preferred one for its standard of scholarship, his wife preferred another for the companions the boy would have. As a way out of the dilemma they decided not to send the boy away (the question had been of a boarding-school), but to keep him at home where his mother could have a good deal to say about his companions and where there was a school his father liked. This was not a compromise because neither gave up anything: the father had a school with standards he respected and the mother was more pleased than with the arrangement first considered. This settlement of the question involved the further decision that the boy should be sent to a summer camp and thus he did get some of the benefits of the boarding-school. (162)

Each example of integration follows a common theme. Two competing options are articulated by the parties who need to come to agreement. In example 1, it is whether to travel by boat or by train. In 2, whether to cut the price to be more competitive. Example 3 concerns which of two boarding schools to send the child to. What is crucial to the process of integration is that these options are not taken as either fixed or exhaustive of the possibilities. ${ }^{4}$ Rather, the parties to the discussion step back, examine the goals and values behind their preference for one or the other option, and creatively expand the range of possibilities.

In case 1 , the airplane presents the possibility of getting what is good about both boat and train. The possibility of producing higher-quality paper in example 2 takes one out of the race-to-the-bottom price war, distinguishing one's product from the competition and justifying a higher price and profit margin, better serving the financial goals that drove the cost-cutting in the first place. The choice the parents make in example 3 of a local school rather than a boarding school satisfied the desiderata of both parents, in light of the addition of summer camp to satisfy what both perceived to be better about a boarding school.

In each case, neither of the original choices supported by parties to the decisionmaking is chosen; nevertheless, all the parties are satisfied by the new choice, because it meets the considerations and values that had originally motivated their original 
choice. This is a process of integration because the initial values that seemed in conflict or competition are not sacrificed or compromised but all satisfied. It is creative because it requires multiplying options and exploring new types of solution. In cases 1 and 3 the solution requires the fortuitous presence of the ability to recognize and the flexibility take advantage of new opportunities. This flexibility is one aspect of adaptability, as is the willingness to switch gears and change branding and possibly the nature of the production process in case 2 . These creative integrations also are a key part of individual decision-making where our values and desires seem to conflict or pull us in different directions.

\section{EMPIRICALLY AND PRAGMATICALLY RIGOROUS}

Follett's writings are striking in a number of ways. She insists on conceptual clarity and rigor. However, she argues that armchair philosophy cannot give it to us; we need to observe the workings of the real world. She speaks about what social science can learn from physics and from psychology, but she insists that genuine social science must focus on human relationships in situ. She appropriates the term "participant-observer" from anthropology for the kind of relationship the theorist must have to practice. She moves from the heights of idealist philosophy, through technical empirical psychology and biology, to anecdotes from labor unions and business leaders, weaving all of this together into a general theory with many clear applications.

All pragmatist philosophers talk about grounding philosophical theorizing in human practice, for the purposes of guiding improvement of those practices; this broad generalization is true if there is any substance behind the term pragmatism. More than any pragmatist thinker I have encountered, save Addams, Follett follows through on this core commitment in her own theoretical and practical work, starting from her work in Boston and working outward into broader contexts of practice. Her on-the-ground interventions in practice occasion philosophical reflection, and her philosophical reflections guide new practical endeavors.

Follett worked with labor unions and business owners, but she argued for a very different, more participative and democratic approach than the adversarial "collective bargaining" model we have become familiar with through the current system of labor organization. The outcomes of the latter process depend on the relative "bargaining power" of each party, which could change arbitrarily. Follett saw significant instability and dissatisfaction as a result of that adversarial process: "If we want harmony between labor and capital, we must make labor and capital into one group: we must have an integration of interests and motives, of standards and ideals of justice" (Follett 1918, 117). Follett argued that it was ultimate "joint control" of industry by employers and employees that would create the necessary recognition of shared interest and the possibility of integrative solutions.

Follett proposed many "experiments in democracy" to effect such integration on a large scale. In The New State, Follett laid out her model of "federalism," according to which the process of integration would occur at multiple levels of organization. In her "true federal state," the individual's values or desires are not "sacrificed" in the process of integration, nor are those belonging to the lower levels of organization. The result was a kind of harmony-in-diversity. Follett herself criticized what she called "pluralism," based on the common usage of that term in early twentieth-century politics (see Whipps 2014). The pluralism Follett criticized required relatively fixed identity, cultural, or national groups whose interests tended to be misinterpreted as 
fundamentally "antagonistic" (Follett 1918, 114, 119-20). Nonetheless, although it is not her terminology, her view could reasonably be seen as a kind of pragmatic and integrative pluralism. ${ }^{5}$

In Creative Experience, she develops the plans for a participatory democratic experiment that she called "experience meetings":

The first step in these would be to present the subject under consideration in such a way as to show clearly its relation to all our daily lives. This is very important and usually neglected; I have never heard anyone tell people the actual difference in their own lives a League of Nations might make. The second step would be for each one of us to try to find in our own experience anything that would throw light on the question. I am hoping that this might prove sufficiently interesting to induce us to put up with the "accurate information." Also that after such meetings have become a part of our community life, we should begin to observe and analyze our experience much more carefully than we do at present; it is almost wholly insignificant to us now as having social value. And I am hoping much more than this: that we shall take an experimental attitude toward our experience, and have many experiments to report with reasons for their success or failure, and suggestions as to what direction new experiments should take. The third step would be to see if we could unite our various experiences, one with the other and with the material provided by the expert. The material of the expert would always thus be thrown into the situation, not put up for acceptance or rejection. In the case of the farmer, get his experience and add to that of the agricultural expert. The scientific manager in the factory needs the experience of the workman. The Red Cross agent in the village needs the experience of the mother. We want to be governed neither by experts nor by the "innate" ideas of an all-born-equal people; what we want is cooperating experience, which means cooperating activity, which means a progressively more efficient activity. (Follett 1924, 212)

Several key items are notable in this passage. One is the emphasis on experience, not in the sense of "empirical data" but rather the accumulated experience of one's practical life. This notion of experience is not only "lived experience" but also perspectival, a kind of situated knowledge. Second, and related, the expert is treated not as an epistemic authority but as one standpoint among others, all of which are needed in cooperation; nevertheless, experts and the information they bring play a crucial role in the process. The third point is the experimental approach, not in the sense of controlled laboratory conditions, but in the sense of testing out different attitudes and approaches to problems on the basis of discussions in prior experience meetings. In the background here, the notion of integration is also at work; it is the process by which cooperative activity results in shared decisions.

\section{ACCESSIBILITY AND COMMUNICATION}

Many have commented on the qualities of Follett's writing. I have attempted to exhibit Follett's communication skills by quoting her work at length; it requires little further comment. As mentioned above, Snider has argued that Follett is particularly adept at adapting her writing style or "voice" to different audiences. Snider points out that Follett's philosophical writings have an "elegant style," but he also shows how she moves from this style toward one founded on concrete examples and personal experience, adopting new vocabulary to make her audience more comfortable with her ideas 
(Snider 1998, 280). Whipps tells us that Follett writes "with passion and eloquence" (Whipps 2014, 413). Tonn frequently alludes to the rhetorical and emotional function of Follett's writing style, calling it "passionate" and "stirring" (Tonn 2003, 307, 383).

Sometimes Follett's "vivid rhetoric" and "passionate prose" made some in her scientific and philosophical audiences, in particular, uneasy (Tonn 2003, 301, 307; cf. Stout and Love 2014, 13; McKenna and Pratt 2015, 126). In many cases her writing errs on the side of the informal, which again makes it more broadly accessible, though sometimes offending a more scholarly audience. Follett was particularly concerned about the deleterious effect of jargon (Tonn 2003, 320). Public philosophers should learn a lesson from Follett: avoid jargon, write in an accessible way, and translate ideas into an idiom your audience can understand and identify with.

\section{FOLLETT AS A MODEL FOR PUBLIC PHILOSOPHY}

I have attempted to distill Follett's public philosophical approach to five major points, and to explain or demonstrate each of these in her life and work: 1 . Her writing is thoroughly engaged in society, politics, and life. 2 . It is voraciously interdisciplinary across a wide variety of fields. 3. Follet's work is adaptable and opportunistic (in a good way) to the needs and resources of her situation. 4. She models a pragmatic sort of rigorousness, and 5. her writing is accessible. Her work deserves further exploration by public philosophers as a model for future work.

As with other pragmatist philosophers like William James and John Dewey, Follett emphasizes the importance of experience and activity. As with Dewey and Jane Addams, Follett emphasizes the importance of cooperation, growth, and inclusive or "lateral" progress. Like Addams's, Follett's philosophy developed in response to, and was used to aid, her engaged social projects. Although Dewey and Addams both preached, and to some extent practiced, the idea of situational specificity of ideas, Follett perhaps even more so showed an adaptability, an ability to shift her focus and her idiom as opportunities arose, to creatively integrate her own ideas to the needs of particular situations and publics. She gathered ideas from a variety of sources and disciplines, as well as her own experience and the experience of others, to craft careful but accessible arguments aimed at transforming practice. Follett used her ideas about integration and creativity to address real social problems. In this way, Follett presents a model of public philosopher from whom we have much to learn.

How can Follett, as a model for public philosophy, help us think through the divisive, partisan world we live in? She provides ways of thinking about community and democracy in a pluralistic, process-oriented, integrative way. She gives us a nuanced way to talk about the different manifestations of power within such processes. Philosophers who want to make a difference in the current scene can learn much from taking Follett as a model. She urges us to avoid abstraction and turn to real-world problems, and to look for and take advantage of opportunities to intervene where they come. She reminds us of the importance of interdisciplinary and empirically informed philosophy, as well as engagement with the public. Her analysis of power and advocacy of power-with rather than power-over, as well as her concept of integration, present a challenge to avoid top-down imposition of preconceived ideas and to work with publics to creatively achieve change. Follett's approach is much needed.

Acknowledgments. My thanks to Evelyn Brister and Nancy McHugh, who organized the 2019 Public Philosophy Network session at the 2019 Society for the Advancement of American Philosophy session 
that was the germ for this essay, and to the audience at SAAP that provided the initial feedback on that paper. My gratitude to Tess Varner, Danielle Lake, and Judy Whipps for inviting me to be a part of this special cluster and encouraging me along the way through a difficult time to be writing, and for their forbearance when the difficulty was acute. My appreciation to Erin McKenna, the anonymous reviewers, and the editors and staff of Hypatia in helping transform this essay into a much more solid work of Follett scholarship.

\section{Notes}

1 Fully tracing Follett's intellectual genealogy or her affiliations with schools like Pragmatism and Idealism is beyond the scope of this essay. I do not here mean to specifically attribute to Follett the epistemological, semantic, or psychological doctrines commonly associated with "American Pragmatism" in the narrow sense. Follett was clearly influenced by Royce and William James. Her contextualism, or the view she called "the law of the situation," is obviously resonant with similar themes in Addams and John Dewey. For more on the connection between Follett and pragmatism, see Evans 1998; Banerjee 2008; Stout and Love 2014; Whipps 2014.

2 In matters of metaphysics, Follett seems to be more of a process philosopher than an Absolute idealist. See Stout and Staton 2011.

3 It is noteworthy that many twentieth-century pragmatist philosophers and social theorists ended up in management theory, broadly construed. See also, for example, C. West Churchman and Russell Ackoff as slightly later examples. Unfortunately, I cannot follow up the point further here.

4 This is the opposite of the common method of reasoning in contemporary normative ethics, where the options are treated as given, fixed, and exhaustive from the start.

5 Compare the related concept in philosophy of science from Mitchell 2002; 2003.

\section{References}

Banerjee, Amrita. 2008. Follett's pragmatist ontology of relations: Potentials for a feminist perspective on violence. Journal of Speculative Philosophy 22 (1): 3-11. http://www.jstor.org/stable/25670684.

Carpenter, Colton. 2019. The divided United States of America. Harvard Political Review, March 18. https:// harvardpolitics.com/columns-old/divided-states/.

Drutman, Lee. 2017. We need political parties. But their rabid partisanship could destroy American democracy. Vox, September 5. https://www.vox.com/the-big-idea/2017/9/5/16227700/.

Evans, Karen Gilliland. 1998. Governance, citizenship, and the new sciences: Lessons from Dewey and Follett on realizing democratic administration. PhD diss., Virginia Polytechnic Institute and State University.

Follett, Mary Parker. 1896. The Speaker of the House of Representatives. New York: Longmans, Green, \& Co.

Follett, Mary Parker. 1918. The new state: Group organization the solution of popular government. New York: Longmans, Green, \& Co.

Follett, Mary Parker. 1919. Community is a process. Philosophical Review 28 (6): 576-88.

Follett, Mary Parker. 1924. Creative experience. New York: Longmans, Green, \& Co.

Follett, Mary Parker. 1942. The giving of orders. In Dynamic administration: The collected papers of Mary Parker Follett, ed. Elliot M. Fox and L. Urwick. New York: Pitman Publishing.

Kaag, John. 2008. Women and forgotten movements in American philosophy: The work of Ella Lyman Cabot and Mary Parker Follett. Transactions of the Charles S. Peirce Society 44 (1): 134-57.

McKenna, Erin, and Scott L. Pratt. 2015. American philosophy: From Wounded Knee to the present. New York: Bloomsbury Press.

Meagher, Sharon M. 2013. Public philosophy: Revitalizing philosophy as a civic discipline. Report to the Kettering Foundation. https:/st4.ning.com/topology/rest/1.0/file/get/2057988196?profile=original.

Mitchell, Sandra D. 2002. Integrative pluralism. Biology and Philosophy 17 (1): 55-70.

Mitchell, Sandra D. 2003. Biological complexity and integrative pluralism. Cambridge: Cambridge University Press. 
Packer, George. 2020. The President is winning his war on American institutions: How Trump is destroying the civil service and bending the government to his will. Atlantic, April. https://www.theatlantic.com/ magazine/archive/2020/04/how-to-destroy-a-government/606793/.

Pratt, Scott L. 2011. American power: Mary Parker Follett and Michel Foucault. Foucault Studies 11 (February): 76-91.

Sherman, Donald K. 2020. Perspective: Trump's corruption is racist, and his racism is corrupt. Washington Post, September 1. https:/www.washingtonpost.com/outlook/2020/09/01/trump-racism-corruption/.

Snider, Keith. 1998. Living pragmatism: The case of Mary Parker Follett. Administrative Theory \& Praxis 20 (3): $274-86$.

Stout, Margaret, and Jeannine M. Love. 2014. The unfortunate misinterpretation of Miss Follett. Public Voices 13 (2): 11-32.

Stout, Margaret, and Jeannine M. Love. 2015. Integrative process: Follettian thinking from ontology to administration. Vol. 5. Toward ecological civilization. Anoka, Minn.: Process Century Press.

Stout, Margaret, and Jeannine Love. 2016. Follett, Mary Parker. In Encyclopedia of public administration and public policy, $3^{\text {rd }}$ ed. New York: Taylor and Francis.

Stout, Margaret, and Carrie M. Staton. 2011. The ontology of process philosophy in Follett's administrative theory. Administrative Theory \& Praxis 33 (2): 268-92. https://doi.org/10.2753/ATP1084-1806330206.

Tonn, Joan C. 2003. Mary P. Follett: Creating democracy, transforming management. New Haven, Conn.: Yale University Press.

Tully, James. 2008. Public philosophy in a new key: Vol. I: Democracy and civic freedom. Cambridge: Cambridge University Press.

Whipps, Judy. 2014. A pragmatist reading of Mary Parker Follett's integrative process. Transactions of the Charles S. Peirce Society 50 (3): 405-24.

Matthew J. Brown is Director of the Center for Values in Medicine, Science, and Technology, Program Head for history and philosophy, and a Professor of philosophy and history of ideas at the University of Texas at Dallas. The main areas of his research deal with the intersection of science with values, the way science informs policy, engineering ethics, and education, and the history and legacy of American pragmatism. His monograph Science and Moral Imagination: A New Ideal for Values in Science (University of Pittsburgh Press, 2020) explores the interplay of science and values from a broadly feminist-pragmatist perspective. <http://www.matthewjbrown.net/>.

Cite this article: Brown MJ (2021). Mary Parker Follett as Integrative Public Philosopher. Hypatia 36, 425-436. https://doi.org/10.1017/hyp.2021.15 